\title{
Relationship between Social Capital and Job Performance among Faculty Members of a Medical University: The Moderating Role of Entrepreneurship Behavior
}

\section{Roohollah Kalhor}

Qazvin University of Medical Sciences Qazvin School of Public Health

Nadia Neysari

Qazvin University of Medical Sciences Qazvin School of Public Health

\section{Saeed Shahsavari}

Qazvin University of Medical Sciences Qazvin School of Public Health

Sima Rafiei ( $\square$ sima.rafie@gmail.com )

https://orcid.org/0000-0002-7502-7078

\section{Research}

Keywords: Entrepreneurial behavior, job performance, social capital, faculty members, medical university

Posted Date: March 16th, 2020

DOI: https://doi.org/10.21203/rs.3.rs-17279/v1

License: (a) (1) This work is licensed under a Creative Commons Attribution 4.0 International License. Read Full License 


\section{Abstract}

Background Job performance is an important organizational factor that plays a significant role in the success of organizations. This study aims to investigate the moderating role of entrepreneurial behavior in the relationship between social capital and job performance among faculty members of Qazvin University of Medical Sciences.

Methods This is a descriptive-analytical study which has been conducted through a structural equation modeling among all university faculty members working in different faculties of Qazvin University of Medical Sciences in 2017. To evaluate the causal relationships between study variables, Structural Equation Modeling (SEM) on AMOS software, with the significant level of 0.05 was used.

Results Findings indicated that entrepreneurial behaviors and social capital could predict job performance. The direct effect of social capital on job performance (path coefficient: 0.17 ) and its indirect effect with the moderating role of entrepreneurial behavior (path coefficient: 0.39) were confirmed $(P<0.05)$. Furthermore, Sobel test affirmed the indirect associations between variables $(P<0.05)$.

Conclusions Strengthening social capital and promoting entrepreneurial behavior can lead to higher levels of performance. Building trust among organizational members and designing new incentive methods which use entrepreneurial indicators for performance evaluation can improve social capital. Therefore, managers can contribute to the improvement of job performance through developing entrepreneurial behavior among their employees.

\section{Background}

Job performance is an important organizational behavior that plays a significant role in the success of organizations. Thus, successful businesses are constantly trying to identify contributing factors in employees' job performance and the way of promoting it [1]. Due to extensive environmental changes in modern societies, it is believed that a key competitive benefit for today's markets is an entrepreneurial risk-taking and strong tendency to develop their intellectual capital [2]. In other words, the existence of skillful, creative, and entrepreneurial human resources not only leads to organizational development, but also contributes to the economic growth of a society [3]. As entrepreneurship is progressively mentioned as a motivational factor for the development of different organizations, it is required to promote entrepreneurship education in universities and higher education systems as a main pillar of an educational system to train creative human resources for future organizations. Furthermore it has been affirmed that an integrated, coherent entrepreneurial culture among university faculty members as the main axis of future work force training can play an important role in the development of entrepreneurial universities [4].

One of the key factors in developing entrepreneurial activities is social capital. In organizations with high levels of social capital, employees are committed to job activities and effective interactions among them bring a strong commitment to organizational values and goals. All these positive behaviors lead to a competitive advantage in organizations which not only bring efficiency and effectiveness but also maximize organizational success [5]. Francis considers social capital as a set of links and relationships among members of a network, which facilitates goal achievement of an organization, through creating trust and mutual interactions [6]. In the 
absence of social capital, other organizational assets lose their effectiveness and make it hard to have progress in the way of cultural and economic development [7]. Social capital also plays a significant role in the development of entrepreneurial activities in any types of organizations; given the fact that entrepreneurship is a socioeconomic process that affects the nature of business through the presence or absence of social interactions and communications [8]. This social phenomenon leads to creativity, and risk taking behaviors among work force, all of which are recognized as key indicators of entrepreneurship [9].

Results of different studies indicated the leading role of entrepreneurial behavior in improved employees' performance [10]. Studies have also mentioned social capital as an effective factor in entrepreneurial behavior [11]. In a study conducted by Chen et al. to investigate the relationship between social capital, entrepreneurial behavior and job performance among employees, results indicated that there was a positive and significant relationship between these three variables. In other words, the results of the study showed that social capital had a significant impact on the entrepreneurial behavior of organizational members [12].

In addition to developing entrepreneurial behavior among employees, managers can help them to improve their job performance through strengthening social capital in organizations. In this regard, universities and higher education systems are the most important fields for the country's development as well as the main sources for training skillful and committed human resources. Inefficiency in this field leads to many problems and irreparable damages to social, economic and cultural aspects of the country [13]. Considering the key role of university faculty members in promoting entrepreneurship culture among learners who constitute tomorrow's work force, it is necessary to investigate their performance by emphasizing on innovative and entrepreneurial dimensions [14]. Understanding the role of social capital in developing such innovative aspects can greatly help managers and policy makers to make evidence-based decisions about effective ways of improving organizational performance [15]. This is especially important in some fields of study such as medical sciences where graduates deal with a wide range of people. Therefore, considering the importance of this issue and the necessity of universities' orientations toward entrepreneurship, this study aimed to investigate the mediating role of entrepreneurial behaviors in the relationship between social capital and job performance among university faculty members of a medical university in Qazvin, Iran.

\section{Methods}

Design

This is a descriptive-analytical study which has been conducted through a structural equation modeling among all university faculty members working in different faculties of Qazvin University of Medical Sciences in 2017.

Setting and Samples

A total of 260 faculty members were selected to participate in the study through consensus method.

Data collection

The data collection tools were as follows: the 25 -items Social Capital Scale, the 12 -items Entrepreneurial Behavior Questionnaire, and a 16-item Job Performance Questionnaire developed by Paterson in 1992 [16, 17]. 
All instruments were rated on a 5-point Likert scale and their validity was approved in similar studies conducted with the same purpose [18-20].

Statistical analysis

To analyze data according to study objectives, descriptive statistical analysis and Pearson correlation coefficient were used examining the relationship between main variables of the study using SPSS software version 20. To test the significance among observer and hidden variables also examine fitness of the model using structural equation modeling (SEM), path analysis through AMOS software was applied. Also the Sobel test and VAF used for measuring the effect and $t-$ value of mediator variables.

\section{Results}

Of the total 260 faculty members in Qazvin Medical University, the participation rate was $80.7 \%$ (210 people); among which the highest participation belonged to females (54.3\%), those in the age group of 54 - 45 years (38.1\%), and married individuals (80.9\%). In terms of education, the most number of participants were specialists (36.7\%) with an academic level of assistant professor (61.4\%). Also, the highest percentage of participants had more than 10 years work experience (49\%), working in the faculty of medicine (44.5\%) (Table 1). 
Table 1

Demographic Characteristics of Study Participants

\begin{tabular}{|c|c|c|c|}
\hline \multicolumn{2}{|l|}{ Demographic variables } & \multirow{2}{*}{$\begin{array}{l}\text { Frequency } \\
96\end{array}$} & \multirow{2}{*}{$\begin{array}{l}\text { \% Frequency } \\
45.7\end{array}$} \\
\hline Gender & Male & & \\
\hline & Female & 114 & 54.3 \\
\hline \multirow[t]{4}{*}{ Age groups } & $20-34$ & 44 & 21 \\
\hline & $35-44$ & 76 & 36.2 \\
\hline & $45-54$ & 80 & 38.1 \\
\hline & More than 55 & 10 & 4.8 \\
\hline \multirow[t]{3}{*}{ Marital status } & Married & 169 & 80.9 \\
\hline & Single & 39 & 18.7 \\
\hline & Others & 1 & 0.5 \\
\hline \multirow[t]{4}{*}{ Educational level } & Master degree & 31 & 14.8 \\
\hline & $\mathrm{PhD}$ & 65 & 31 \\
\hline & Specialty & 77 & 36.7 \\
\hline & Sub-specialty & 37 & 17.6 \\
\hline \multirow[t]{5}{*}{ Academic level } & Educational staff & 11 & 5.2 \\
\hline & Instructor & 30 & 14.3 \\
\hline & Assistant professor & 129 & 61.4 \\
\hline & Associate professor & 36 & 17.1 \\
\hline & Full professor & 4 & 1.9 \\
\hline \multirow[t]{4}{*}{ Years of work experience } & $1-3$ & 44 & 21 \\
\hline & $3-5$ & 23 & 11 \\
\hline & $5-10$ & 40 & 19 \\
\hline & More than 10 & 103 & 49 \\
\hline \multirow[t]{5}{*}{ Faculty } & Medicine & 93 & 44.5 \\
\hline & Dentistry & 50 & 23.9 \\
\hline & Health & 25 & 12 \\
\hline & Nursing and Midwifery & 31 & 14.8 \\
\hline & Paramedical & 10 & 4.8 \\
\hline
\end{tabular}


Since the model was fitted to data, the path coefficient (direct effect) of each path was observable. The path coefficient is a numerical standard between 1 and _ 1 . In the final model, positive sign indicates the positive relationship among the considered factors. For example, the path coefficient between Social capital and Job Performance was 0.17. However, to examine the significance of this coefficient, Student's t statistics corresponding to each coefficient was employed and the values are presented in Fig. 1.

According to data reported in Table 2, According to the conducted path analysis, all t statistics were greater than 1.96, indicating that all path coefficients were significant at a confidence interval of $95 \%$; therefore, all path coefficients were significant. As a result, it can be concluded that the study's hypotheses are approved (Table 2). The standardized load factor reported for the relationship between social capital and job performance was $17 \%$, while the same regarding to the relationship between entrepreneurial behavior and job performance was $24 \%$. In other words, one unit change in standard deviation of these two variables would respectively change the standard deviation of job performance about $17 \%$ and $24 \%$. Moreover, to determine the strength of mediation, variance accounted factor (VAF) was calculated. VAF determines the size of indirect effect compared to direct effect. The calculated value of VAF in this study was $39 \%$. Therefore, it can be concluded that entrepreneurial behavior partially mediates the relationship between social capital and job performance. Further, to confirm the mediation SOBEL test was employed and the result was found significant. Hence, Hypothesis of relationship between social capital and job performance is mediated by entrepreneurial behavior is accepted (Test statistic $=2.31$, Std. Error $=0.047, \mathrm{p}$-value $=0.02$ ). 
Table 2

Results of the Estimated Model by Factor Loadings (Path Coefficients) and T Statistics

\begin{tabular}{|c|c|c|c|c|c|c|c|}
\hline hypothesis & Component & Direction & Variable & $\begin{array}{l}\text { Standardized } \\
\text { load factors }\end{array}$ & $\mathrm{T}$ & $\begin{array}{l}P \text { - } \\
\text { value }\end{array}$ & result \\
\hline $\mathrm{H} 1$ & Social capital & $\begin{array}{l}\text { Please } \\
\text { click here } \\
\text { to } \\
\text { download } \\
\text { the } \\
\text { original } \\
\text { image file } \\
\text { Click } \\
\text { here to } \\
\text { Correct }\end{array}$ & $\begin{array}{l}\text { Job } \\
\text { Performance }\end{array}$ & 0.17 & 2.08 & $\begin{array}{l}< \\
0.05\end{array}$ & Accepted \\
\hline $\mathrm{H} 2$ & Social capital & $\begin{array}{l}\text { Please } \\
\text { click here } \\
\text { to } \\
\text { download } \\
\text { the } \\
\text { original } \\
\text { image file } \\
\text { Click } \\
\text { here to } \\
\text { Correct }\end{array}$ & $\begin{array}{l}\text { Entrepreneurial } \\
\text { behavior }\end{array}$ & 0.45 & 5.11 & $<.05$ & Accepted \\
\hline H3 & $\begin{array}{l}\text { Entrepreneurial } \\
\text { behavior }\end{array}$ & $\begin{array}{l}\text { Please } \\
\text { click here } \\
\text { to } \\
\text { download } \\
\text { the } \\
\text { original } \\
\text { image file } \\
\text { Click } \\
\text { here to } \\
\text { Correct }\end{array}$ & $\begin{array}{l}\text { Job } \\
\text { Performance }\end{array}$ & 0.23 & 2.55 & $\begin{array}{l}< \\
0.05\end{array}$ & Accepted \\
\hline
\end{tabular}

In examining the study hypothesis using structural equation model, software output affirmed the suitability of structural model (Table 3).

Table 3

Fitness Indicators of Structural Equation Modeling

\begin{tabular}{|lcccccc|}
\hline Fit index & AGFI & GFI & CFI & SRMR & RMSEA & X $^{2} / \mathbf{d f}$ \\
\hline Acceptable value & $>0.9$ & $>0.9$ & $<0.9$ & $>0.05$ & $<0.05$ & $<3$ \\
\hline Fit index & 0.61 & 0.64 & 0.91 & 0.047 & 0.043 & 2.24 \\
\hline
\end{tabular}

The obtained value for GFI as one of the fitting goodness indicators affirms the model fitness (0.64). Also, the ratio of $\chi^{2}$ on degree of freedom is one of the best indicators of model fitness, which shows the value of 2.24 in an acceptable range. Furthermore, the RMSEA index estimated by the errors of the model is 0.043 , reflecting the optimal level. 


\section{Discussion}

Findings of this study revealed that there was a relatively good status in terms of social capital, entrepreneurial behavior and job performance among study participants. Regarding social capital, findings were in line with Ghanbari and Navidi and Abili and Zare-Khalili studies [19, 21]. Also, the moderate to high status of job performance among faculty members was in agreement with findings obtained from Nasiri and Azarnosh et al. study $[22,23]$.

Results regarding the investigation of relationship between social capital, entrepreneurial behavior and job performance among study participants revealed a significant relationship between these variables, with the moderating role of entrepreneurial behavior. These findings are consistent with Karimi et al. study, which affirmed the mediating role of entrepreneurial behavior in the relationship between social capital and job performance [24].

In addition, our research confirmed a direct and significant relationship between social capital and job performance; so that strengthening social capital in the workplace increased job performance among university faculty members. This result was also confirmed by findings of several studies [19, 25-27]. The importance of examining such a relationship between these variables in an organizational environment is related to the fact that each organization is looking for effective and efficient strategies to achieve determined goals and enhance the level of job performance among their members [28]. According to various researches, one of the most effective factors in job performance is social capital in the workplace, which enhances job performance through the reciprocal recognition and trust among members and effective sharing of information, knowledge and work experiences [29]. Due to the importance of social capital and its impact on educational system of a society, our study results confirmed that constructive communication among university faculty members acts as an effective factor in enhancing the quality of education as well as promotion of occupational activities [30]. Literature affirmed the importance of social capital as an influencing factor on personnel job performance with its significant dimensions including trust, commitment, and mutual interactions [19, 22, 31, 32]. Nahapiet and Ghoshal explained that trust among organizational members occurs when individuals accept common norms and values of an organization and act upon them. Following common norms and objectives is the basis for improvement in job performance as well as employees' motivation to work more committed toward organizational goals. In other words, it can be concluded that employees who perceive an appropriate level of social capital in their workplace behave more positively in interactions with their colleagues. As a result of these effective interactions, employees feel satisfied with their work and experience higher degree of commitment toward their career goals [16].

On the other hand, study results affirmed a significant direct relationship between social capital and entrepreneurial behavior among faculty members, which had been confirmed in similar researches [33-36]. In fact, effective communication provides opportunities for knowledge and experience sharing among organizational members which leads to a cooperative-like competition [37]. In fact, an organization with a high level of social capital is able to foster new ideas and strengthen creativity through an effective transferring of knowledge. This creativity eventually leads to innovation and entrepreneurship in an organization. Therefore, a firm which has a desirable level of social capital can potentially be regarded as an entrepreneurial organization [38]. 
Findings about the direct impact of entrepreneurship on job performance are consistent with studies which confirm a significant relationship between entrepreneurial characteristics and job performance [20,39]. This result suggests that the more entrepreneurial orientation among organizational members can lead to higher levels of job performance. In fact, change in employees' behavior toward entrepreneurial culture could significantly predict the level of job performance; meaning that the more employees have higher risk-taking, and innovative behavior, the more they will be expected to have higher levels of job performance [40]. In other words, entrepreneurial orientation is associated with some of the characteristics including innovation, risktaking, and revolutionary change. Thus, in order to realize these features at different organizational levels, managers should motivate employees to strengthen their entrepreneurial spirit and consequently achieve high levels of performance.

\section{Conclusions}

Given the fact that, educational institutions, including universities are responsible for training knowledgeable and skillful workforce needed to work in future firms and institutions, it is essential to pay special attention to the significant role of university faculty members as central aspects of a community education system and move toward strengthening their performance. Our study findings revealed that strengthening social capital and promoting entrepreneurial behavior among these members can lead to higher levels of performance. Furthermore, obtained results confirmed that building trust among organizational members can improve social capital. Designing new incentive methods which use entrepreneurial indicators as employees' performance indices is also recommended. On the other hand, social capital has an important role in the emergence and development of entrepreneurial activities. Therefore, managers can contribute to the improvement of job performance, in addition to developing entrepreneurial behavior among their employees.

\section{Declarations}

Acknowledgements: Not applicable.

Authors' Contributions: SR planned the study, NN collected data, RK and S SH analyzed the study data and SR drafted the manuscript. All authors have read and approved the final manuscript.

Funding: Not applicable.

Availability of data and materials: Data are available upon reasonable request.

Ethics approval and consent to participate: Ethics committee, Qazvin University of Medical Sciences, and study protocol ID: IR.QUMS.REC.1396.1

Consent for publication: All authors have approved the manuscript for submission.

Competing interests: Authors declared no conflict of interest.

\section{References}


1. HosseinabadiB., Etemadinezhad S., khanjani N., et al. Evaluating the relationship between job stress and job satisfaction among female hospital nurses in Babol: An application of structural equation modeling. Health Promotion Perspectives 2018; 8: 102-108.

2. Bhagavatula S., Elfring T., Tilburg A., et al. How Social and Human Capital Influence Opportunity Recognition and Resource Mobilization in India's Hand loom Industry. Journal of Business Venturing, 2010; 25(3): 245-260.

3. Frese M., Gielnik M.M. The psychology of entrepreneurship. Annual Review of Organizational Psychology and Organizational Behavior, 2014; 1: 413-438.

4. Rothaermel F.T., Agung S.D., Jiang, L. University entrepreneurship: a taxonomy of the literature”, Industrial and Corporate Change, 2007; 16(4): 69.

5. Ardichvili A., Cardozo R., Ray S. A theory of entrepreneurial opportunity identification and development", Journal of Business Venturing, 2008; 18(1): 105-123.

6. Sauermann J. Performance measures and worker productivity”, IZA World of Labor, 2016; 260.

7. Adler P.S., Kwon S.W. Social Capital: Prospects for a New Concept, The Academy of Management Review, 2002; 27: 17-40.

8. Bolino M. Citizenship behavior and creation of social capital in organizations, The Academy of Management Review, 2002; 27: 22.

9. Cohen W.M., Levinthal D.A. Absorptive capacity: a new perspective on learning and innovation, Administrative Science Quarterly, 1990; 35: 128- 152.

10. Jalali A., Jaafar M., Ramayah Th. Entrepreneurial orientation and performance: the interaction effect of customer capital, World Journal of Entrepreneurship, Management and Sustainable Development, 2014; 10: 48-68.

11. Stam W., Elfring T. Entrepreneurial orientation and new venture performance: The moderating role of intraand extra-industry social capital, Academy of Management Journal, 2008; 51: 97-111.

12. Chen C., Tzeng Ch.L., Ou M.W., et al. The Relationship among Social Capital, Entrepreneurial Orientation, Organizational Resources and Entrepreneurial Performance for New Ventures, Contemporary Management Research, 2007; 3: 213-232.

13. Mirkamali M., Narenji Sani F. A Study on the Relationship between the Quality of work life and job Satisfaction among the Faculty Members of the University of Tehran and Sharif University of Technology, Quarterly Journal of Research and Planning in Higher Education. 2008; 14: 71-101.

14. Zaker Salehi GH. Paradox of Social Capital of Iranian Students. The Study of the Relationship between Higher Education and Social Capital in Iran. Iranian Engineering Education Quarterly, 2008; 10: 25-50.

15. Rahimi H., Aghababaei R. The Relationship between Social Capital and the Improvement of the Quality of the Workplace of the Faculty Members of Kashan University, Social welfare Research Journal. 2013; 14: 199-225.

16. Nahapiet J., Ghoshal S. Social capital. Intellectual capital and the organizational advantage. Academy of Management Review, 1998; 23: 242-266.

17. Zampetekis L. A., Moustakis, V. Entrepreneurial behavior in the Greek public sector", International Journal of Entrepreneurial Behavior Research, 2007; 13(1): 19-38. 
18. Azadi R., Eydi H. The effects of social capital and job satisfaction on employee performance with organizational commitment mediation role (Case Study, Youth and Sports Ministry), Organizational Behavior Management in Sport Studies, 2016; 2: 11-24.

19. Ghanbari S., Hemati M. The relationship between social capital and job performance of Bu Ali Sina University staff", Higher Education Letter, 2016; 9: 115-133.

20. Asadnia A., Movahedian G., Saghaei Talab M. Case study of staff of public libraries in Zanjan province: Measurement of organizational entrepreneurship behavior of staff of public libraries. Journal of Information and Knowledge Management; 2017; 2: 71-81.

21. Abili Kh., Khalili M. The Relationship between Organizational Social Capital with KM in a State-owned Insurance Company", Insurance Newsletter; 2013; 28: 129-152.

22. Nasiri V.F. The Relationship between Perceived Organizational Protection of Urban Management with Social Responsibility and Municipal Employees' Job Performance of Hamadan, Journal of Urban Economics and and Management, 2014; 2: 97-108.

23. Azarnosh F., Hashemi A., Naami A. The relationship between psychological empowerment and job performance with the mediation of job attitudes in Maroon-Ahwaz oil and gas exploitation company employees. Journal of Psychology Achievements, 2014; 21: 181-204.

24. Karimi S., Shahdosti M. From Social Capital to Job Performance: The Mediating Role of Entrepreneurial Orientation in Hamadan Agricultural Jihad Organization 2017; 10: 53-61.

25. Nemati M.A., Akbarzadeh Safooei M., Zangiyan S., et al. The Role of Social Capital, Commitment, and Organizational Citizenship Behavior in Improving Job Performance (Case Study: Khoy Municipality), Journal of Urban Economics and Management, 2017; 5: 115-132.

26. Alinajafi, Askarinejad M., Veiseh S., et al. The relationship between social capital and employee participation in Gorgan medical science university, Management Science Letters, 2012; 2: 819-826.

27. Ben Hador B. How Intra organizational Social Capital Influences Employee performance, Journal of Management Development, 2016; 35: 1119-1133.

28. Ellington J.K., Wilson M.A. The Performance Appraisal Milieu: A Multilevel Analysis of Context Effects in Performance Ratings, Journal of Business and Psychology, 2017; 32: 87-100.

29. Rosen Ch.C, Kacmar K.M., Harris K.J., et al. Workplace Politics and Performance Appraisal, Journal of Leadership and Organizational Studies, 2016; 24: 20-38.

30. Andrews R. Social Capital and Public Service Performance: A Review of the Evidence, Public Policy and Administration, 2011; 27: 49-67.

31. Saki R., Asare A., Shabani R. The Relationship between Professional Ethics of Managers and Transformational Leadership with Teachers' Job Performance in High Schools in Malard County", Quarterly Journal of Educational Leadership and Administration, 2015; 9: 27-50.

32. Alirezaie N., Masah H., Akrami N. Relationship work ethic and job performance", Journal of Ethics in Science and Technology, 2013; 8: pp. 1-11.

33. Beltran-Martin I., Bou-Liusar J.C. Examining the intermediate role of employee abilities, motivation and opportunities to participate in the relationship between HR bundles and employee performance, BRQ Business Research Quarterly, 2018; 21: 99-110. 
34. Gholipoor R., Madhoushi M., Jafarian V. Analysis of the relationship and effect of social capital on organizational entrepreneurship, Organizational Culture Management, 2008; 6: 111-129.

35. Moharam Zade M., Kashef M., et al. Relationship of Social Capital and Organizational Entrepreneurship in the General Department of Physical Education of West Azarbaijan Province, Research in Sport Sciences 2010; 26: 123-139.

36. Samadi P., Shirzadi H. Investigation the relationship between organizational climates of school with entrepreneurial spirit in students, Journal of Educational Innovations, 2007; 5: 164-187.

37. Rodrigo-Alarcón J., García-Villaverde P. M., Ruiz-Ortega M. J., et al. From social capital to entrepreneurial orientation: The mediating role of dynamic capabilities, European Management Journal, 2017; 35: 785793.

38. Sengupta A. Social Capital and Entrepreneurship: An Analysis of Methodological Issues. Sociological Bulletin 2010; 59: 323-344.

39. Bandiera O., Barankay I., Rasul I. Social incentives in the workplace. Review of Economic Studies, 2010; 77: 417-458.

40. Askaroghli N., Abedi R. The Effect of Entrepreneurial Personality on Employee Job Performance by Empowerment Mediation, Entrepreneurship Development Journal, 2013; 6: 105-124.

\section{Figures}

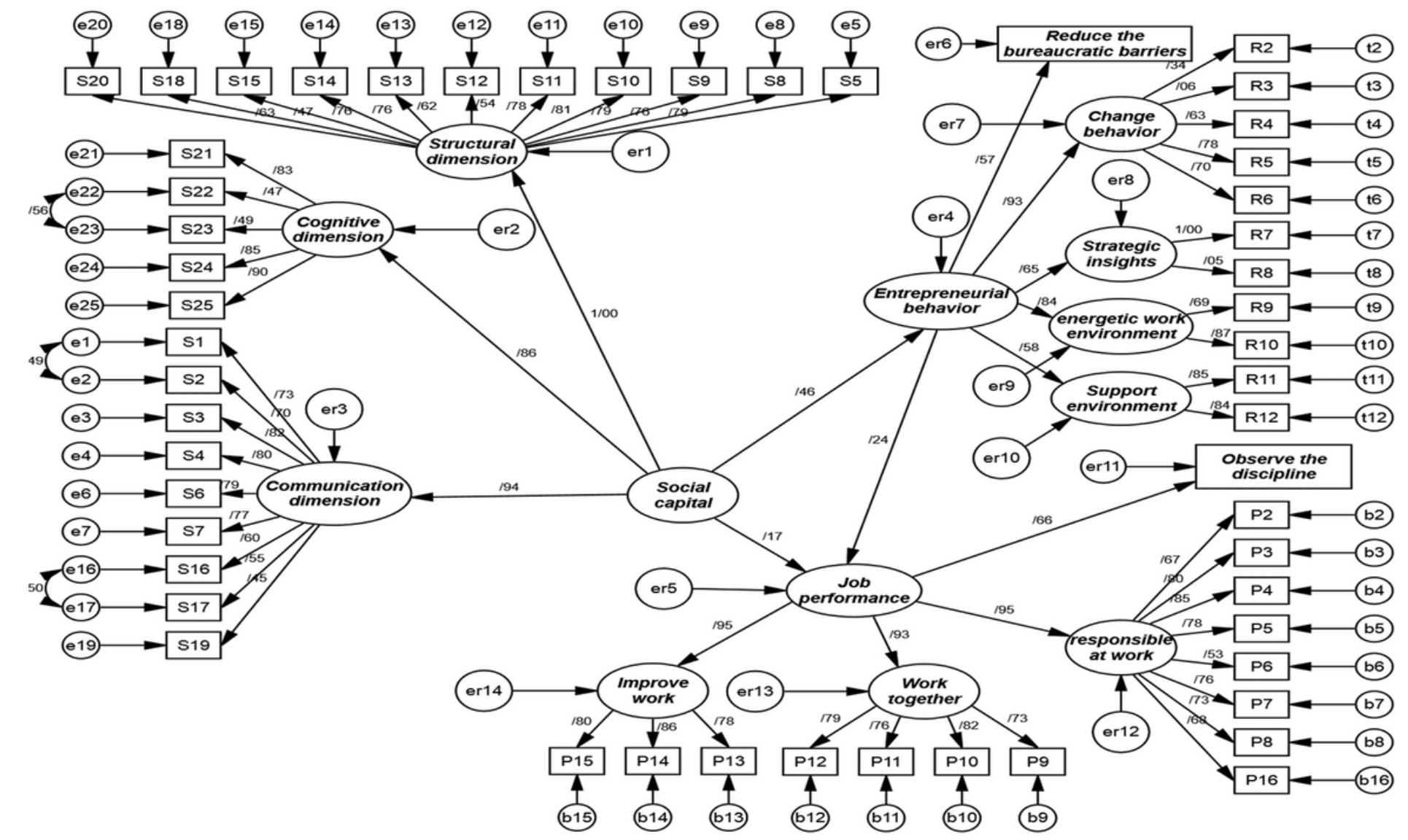

Figure 1 
Factors for estimating the standard factor analysis of the final model 